Janusz Szymański

\title{
PODSTAWOWE INSTRUMENTY PRAWNE WSPÓEPRACY TRANSGRANICZNEJ W RAMACH RADY EUROPY
}

\section{Uwagi wstępne}

Nieodłącznie z rozwojem współpracy międzynarodowej państw wiążą się społeczno-gospodarcze procesy integracyjne społeczności lokalnych i regionalnych. Poszukiwanie wspólnych cech, rozwiązywanie wspólnych problemów, wspieranie ruchów zjednoczeniowych oraz pogłębianie integracji regionów są szczególnie charakterystycznym zjawiskiem w życiu współczesnej Europy.

Państwa przestają być najważniejszymi aktorami na scenie międzynarodowej. Na przestrzeni ostatnich lat stosunki międzynarodowe uległy znacznej decentralizacji, a system międzynarodowy wypełnia wiele podmiotów. Obecnie władze centralne państw muszą dzielić przestrzeń międzynarodową z władzami regionalnymi i lokalnymi. Wpłynęło to na zmianę w tradycyjnym podziale zadań. Władze regionalne i lokalne mają wpływ na sprawy wewnątrzpaństwowe, ale także i na politykę zagraniczną. Władze te wpływają także na procesy integracyjne w ramach Unii Europejskiej. Samorząd terytorialny jest nieodłącznym uczestnikiem tych procesów, a jednocześnie poddany jest ich oddziaływaniom i skutkom. ${ }^{1}$

Władze regionalne i lokalne mogą obecnie skutecznie oddziaływać na rozwój państw - czynią to, podejmując m.in. współpracę transgraniczną. Wola współpracy w regionach transgranicznych w latach 50-tych XX wieku stała się koniecznością życiową dla tychże regionów, ponieważ nigdzie bardziej niż właśnie na terenach granicznych nie uwidacznia się tak istotnie potrzeba przełamywania różnorakich barier. Pierwsze regulacje międzynarodowe, określające wspólne definicje i modelowe mechanizmy podejmowania współpracy transgranicznej, pojawiły się dopiero w 1980 roku, a wypracowane zostały w ramach Rady Europy. Do chwili obecnej Europejska Konwencja Ramowa o Współpracy Transgranicznej między Wspólnota-

J. Kukułka, Teoria stosunków międzynarodowych, Warszawa 2000, s. 217. 
mi i Władzami Terytorialnymi² stanowi podstawowe źródło inspiracji podejmowania współpracy między regionami, a wypracowana definicja współpracy transgranicznej ${ }^{3}$ ma charakter uniwersalny.

Unia Europejska stanowi szczególnie istotne zaplecze finansowe dla działań podejmowanych przez regiony. Świadczą o tym liczne inicjatywy i programy (typu: INTERREG czy programy Europejskiego Instrumentu Sąsiedztwa i Partnerstwa) skierowane do władz regionalnych i lokalnych państw członkowskich. Bez wsparcia finansowego Unii regiony nie byłyby w stanie podejmować się rozwiązywania np. problemów infrastrukturalnych, tym bardziej że regiony państw UE współpracują także z ich odpowiednikami w państwach sąsiedzkich niebędących członkami Unii.

Współpraca regionalna i transgraniczna w ramach państw Unii Europejskiej wpływa w głównej mierze na rozwój gospodarczy poszczególnych regionów. O wiele trudniejsze zadanie stoi przed współpracującymi regionami unijnymi z jednej strony, a ich odpowiednikami z państw trzecich z drugiej. Nie chodzi tylko o rozwój gospodarczy, ale podejmowane są również próby rozwiązywania problemów związanych z lokalną demokracją, praworządnością, dobrą administracją publiczną, zwalczaniem przestępczości i zwiększeniem bezpieczeństwa oraz edukacją i kulturą. ${ }^{4}$

W tworzenie się wizji rozszerzającej się i jednoczącej Europy nieodłącznie wpisuje się problem znaczenia współpracy regionów przygranicznych w rozwój społeczności lokalnych. Współpraca transgraniczna podejmowana przez społeczności na polskich pograniczach, zwłaszcza wschodnich, posiada pewne cechy specyficzne, charakterystyczne dla każdego z nich z osobna. Dzięki podejmowanej współpracy można stwierdzić, że to regiony tak naprawdę stanowią podstawę w realizacji „odgórnych” inicjatyw w zakresie współpracy transgranicznej (w tym Partnerstwa Wschodniego).

Działalność regionów europejskich znacznie wykracza poza ramy polityki regionalnej Unii Europejskiej. Coraz częściej regiony UE podejmują ścisłą współpracę ze swoimi odpowiednikami z państw trzecich. Regiony także nie ograniczają się tylko do ścisłej współpracy w rejonie wspólnych granic, lecz stosunkowo często współpraca taka ma wymiar transregionalny. Działalność władz terytorialnych staje się w bardziej odczuwalny sposób charakterystycznym przykładem przekraczania przez regiony granic krajowych i barier narodowych. Kontakty wzajemne regionów są rodzajem aktywności bardzo zbliżonym w swym charakterze do stosunków między państwami. Jednak euroregiony nie posiadają osobowości prawnej, co po- 
woduje, że ich działalność nie może być traktowana jako aktywność międzynarodowa sensu stricto. Działalność regionów stanowi jednak element polityki zagranicznej państwa w zakresie stosunków sąsiedzkich z innymi państwami. ${ }^{5}$

Współpraca regionów (władz terytorialnych) ma podłoże przede wszystkim ekonomiczne, ale implikuje także polityczne i społeczne skutki. W takiej współpracy liczy się przede wszystkim teraźniejszość i przyszłość, zaś zaszłości historyczne odchodzą na dalszy plan. Współpraca regionów opiera się w głównej mierze na dwóch podstawowych zasadach:

- kontaktach międzysąsiedzkich (dotyczy to obszarów bezpośrednio do siebie przylegających pod względem geograficznym);

- regionalnym bądź lokalnym charakterze wzajemnych stosunków. ${ }^{6}$

Z politycznego punktu widzenia współpraca regionów pozwala jednak na niwelowanie zaszłości historycznych między państwami Europy. Wzajemne stosunki regionów promują dobrosąsiedzkie relacje, a także sprzyjają wzmocnieniu procesów integracji przez zbliżanie do siebie sąsiadujących społeczeństw. W dobie integracji europejskiej regiony stają się liczącym partnerem nie tylko dla instytucji unijnych i europejskich, ale i także dla państw. ${ }^{7}$

W społecznym wymiarze współpraca regionów sprowadza się do wzajemnego poznania i zbliżania kultur. Dzięki takiej współpracy spotykają się i poznają społeczności o różnych zwyczajach, tradycjach i językach. Celem współpracy regionów ma być poznawanie się i nawiązywanie dobrych kontaktów sąsiedzkich, a nie zacieranie różnic między kulturami. Wymiar społeczny współpracy regionów przejawia się także w inny sposób. Nierzadko granice państwowe oddzielają od siebie terytoria historycznie ze sobą powiązane. Przede wszystkim II wojna światowa sprawiła, że obszary te zostały podzielone wbrew woli i poczuciu przynależności ich mieszkańców. Dzięki współpracy regionów terytoria takie mogą się jednoczyć i współdziałać pomimo dzielących je formalnie granic państwowych. ${ }^{8}$

Najważniejsze ze wszystkich przesłanek współpracy regionów wydają się być kwestie ekonomiczne. Otóż współpraca taka jest szansą na zapewnienie zrównoważonego rozwoju terytorialnego. Regiony mogą prowadzić współpracę w zakresie

- ochrony środowiska;

K. Tomaszewski, Regiony w procesie integracji europejskiej, Kraków 2007, s. 103-104.

A. Potoczek, Współczesne problemy rozwoju regionalnego i lokalnego, Włocławek 2000, s. 66-70.

K. Tomaszewski, op. cit., s. 112.

P. de Lombarerde, L. van Langenhove, Indicators of regional integration: conceptual and methodological aspects, (w:) (ed.) P. de Lombarerde, Assessment and measurement of regional integration, New York 2006, s. 2628. 
- turystyki i rekreacji;

- handlu;

- badań naukowo-technicznych;

- zaopatrzenia w wodę;

- rozwijania infrastruktury komunikacyjnej;

- przyciagania inwestycji kapitałowych;

- rozwoju małych i średnich przedsiębiorstw;

- $\quad$ swobody świadczenia usług. ${ }^{9}$

O skuteczności tego typu przedsięwzięć świadczą chociażby wykorzystywane fundusze pomocowe z unijnego budżetu na konkretne działania, jak i także wzrastająca liczba inicjatyw euroregionalnych, które sprawnie i efektywnie działają na pograniczach wszystkich państw członkowskich Unii, a także poza nią (np. pogranicze polsko-rosyjskie, pogranicze polsko-białoruskie czy polsko-ukraińskie).

Władze lokalne i terytorialne mają przede wszystkim zadanie zapewnić wszystkim uczestnikom równe szanse korzystania ze współpracy. Jednak zbyt wielkie różnice w rozwoju ekonomicznym (np. Polska i Białoruś) oraz znaczne dysproporcje w poziomie życia moga prowadzić do negatywnych zjawisk. Trudności związane z przekraczaniem granicy nie są jedynymi problemami formalnoprawnymi utrudniającymi wykorzystywanie granicy jako czynnika pobudzającego, a nie utrudniającego rozwój lokalny i regionalny. Istotnym problemem, rzutującym negatywnie na możliwości i zakres współpracy pomiędzy podmiotami publicznymi, jest zróżnicowanie w systemach zarządzania oraz nieczytelność kompetencji administracji publicznej i gospodarczej. ${ }^{10}$

Do katalogu najpoważniejszych utrudnień współpracy regionów zalicza się także:

- słabo rozwiniętą infrastrukturę komunikacyjną;

- zróżnicowany poziom rozwoju społeczno-gospodarczego i zagospodarowania przestrzennego terenów przygranicznych;

- odmienność systemów administracyjno-gospodarczych;

9 Ministerstwo Rozwoju Regionalnego, B. Kawałko, Granica wschodnia jako czynnik ożywienia i rozwoju społeczno-ekonomicznego regionów przygranicznych. Synteza, z http://www.mrr.gov.pl/rozwoj_regionalny/poziom_regionalny/strategia_rozwoju_polski_wschodniej_do_2020/dokumenty/Documents/b3fd8a3c919b4f59a5d7b1be771706a7Kawako.pdf. 
- brak równorzędnego partnera do współpracy;

- ograniczenia natury społecznej (np. negatywne stereotypy, słaba znajomość języka i kultury sąsiadów itp.).

Władze terytorialne powinny powyższe problemy usuwać bądź zmniejszać ich negatywne oddziaływanie. W przeciwnym razie mogą one stać się poważną przeszkodą we współpracy lub też całkowicie uniemożliwić współpracę. ${ }^{11}$

\section{Współpraca transgraniczna i regionalna w regulacjach Rady Europy}

Międzynarodowa współpraca transgraniczna i międzyregionalna stanowi istotny element polityki rozwoju regionów. Współpraca taka zapewnia przepływ doświadczeń pomiędzy regionami z różnych państw, a tym samym wspiera działania zmierzające do podniesienia jakości funkcjonowania instytucji samorządowych; ułatwia rozwój turystyki; zapewnia koordynację rozbudowy infrastruktury po dwóch stronach granicy państwowej; prowadzi do kulturowego i edukacyjnego rozwoju regionu; jest skutecznym narzędziem promocji. Wszystkie te funkcje spełniane przez współpracę międzynarodową regionów sprawiaja, że przyczynia się ona do rozwoju gospodarczego państwa. ${ }^{12}$

Sięgając do genezy rozwoju współpracy transgranicznej w Europie, należy odnieść się do postanowień i regulacji prawnych Rady Europy. To właśnie ta największa obecnie w Europie organizacja międzynarodowa o charakterze koordynacyjnym zaczęła wspierać rozwój współpracy sąsiadujących ze sobą regionów, tworząc właściwe do tego instytucje i podstawy prawne. Dzięki jej legislacjom regiony przygraniczne przestały pełnić funkcję ,peryferii Europy”, stając się ważnym centrum odniesienia dla gospodarki europejskiej. Ich szybki rozwój został powiązany z ogólną poprawą warunków życiowych mieszkańców Europy. Dlatego też przyspieszenie ich rozwoju zostało uznane za ważny cel nie tylko UE. ${ }^{13}$

Rada Europy jest największą europejską organizacją międzynarodową rządowa, powołaną do życia na mocy Traktatu Londyńskiego dnia 5 maja 1949 roku. Głównym celem powołanej wówczas przez dziesięć państw europejskich organizacji było „osiągnięcie większej jedności pomiędzy jej członkami [...]”"14 Aby zreali-

\footnotetext{
11 M. Brulhart, M. Crozetz, P. Koenigx, Enlargement and the EU periphery: The impact of changing market potential, „The World Economy” 2004, vol. 27, nr 6, s. 853-875.

12 M. Kołodziejski, K. Szmigiel, Międzynarodowa współpraca transgraniczna i międzyregionalna w kontekście polityki regionalnej państwa na lata 2007-2013, Warszawa 2004, s. 3.

K. Tomaszewski, op. cit., s. 121.

Statut Rady Europy z 5 maja 1949 roku, Dz.U. z 1994 r. Nr 118, poz. 565, art. 1.
} 
zować cel główny, Rada Europy podjęła szczególnie wzmożone działania w sferach związanych z:

- ochroną praw człowieka, obroną demokracji parlamentarnej oraz rządów prawa;

- rozwojem porozumień o zasięgu kontynentalnym w celu ujednolicenia praktyk społecznych i prawnych poszczególnych państw;

- promocją świadomości europejskiej i tożsamości opartej na wspólnych wartościach i obecnej w różnych kulturach;

- pomocą państwom Europy Środkowej i Wschodniej w przeprowadzeniu reform prawnych, konstytucyjnych i politycznych, wprowadzanych równolegle do reform gospodarczych;

- popieranie i rozwijanie współpracy z innymi organizacjami i instytucjami europejskimi i międzynarodowymi. ${ }^{15}$

Rada Europy zwykle postrzegana jest jako organizacja, której zakres działania ogranicza się do sfery ochrony praw człowieka. ${ }^{16}$ Jednak już podczas procesu jej tworzenia miała stać się gwarantem wykluczającym perspektywy wybuchu kolejnych konfliktów czy wojen. Zwłaszcza zacieśnianie współpracy między państwami oraz promocja rozpoczynania budowy państwa demokratycznego „oddolnie”, jak najbliżej obywatela, są najważniejszymi czynnikami zachowania stabilności w Europie i na świecie. ${ }^{17}$

Idea współpracy lokalnych i regionalnych społeczności i władz wykraczającej poza granice państw narodowych zrodziła się w Europie Zachodniej w latach 50tych XX wieku. Jej pionierami były regiony z pogranicza niemiecko-francuskiego i holendersko-niemieckiego. W niektórych krajach zachodnioeuropejskich, takich jak Hiszpania, Portugalia i Grecja, rozpoczęto współpracę transgraniczną dopiero w latach 80-tych. Umożliwiły ją dokonane przemiany polityczne i rozwój demokracji. Podobne procesy w Europie Środkowej i Wschodniej rozpoczęły się po przemianach ustrojowych na przełomie lat 80-tych i 90-tych. ${ }^{18}$

15 A. Florczak, Rada Europy, (w:) T. Łoś-Nowak, op. cit., s. 271.

16 Chodzi o Konwencję o Ochronie Praw Człowieka i Podstawowych Wolności z 1950 r., Dz.U. z 1992 r. Nr 85 , poz. 427. Konwencja jest uznawana za największy sukces legislacyjny Rady Europy i stworzyła europejski model ochrony praw człowieka. Więcej (w:) R. Kuźniar, Prawa człowieka. Prawo, instytucje, stosunki międzynarodowe, Warszawa 2000; H. Izdebski, Rada Europy. Organizacja demokratycznych państw Europy i jej znaczenie dla Polski, Warszawa 1996; J. Dinsdale, Rola Rady Europy w ustalaniu standardów w zakresie ochrony praw człowieka, (w:) Nietolerancja, rasizm, ksenofobia, red. nauk. H. Machińska, Warszawa 1999.

17 E. Latoszek, M. Proczek, Organizacje międzynarodowe. Założenia, cele, działalność, Warszawa 2001, s. 317.

18 A. Żelazko, Pojęcie współpracy transgranicznej samorządu terytorialnego, PISM Biuro Analiz, Biuletyn nr 24(212) z 9 czerwca 2004, s. 1137-1138. 
Zasadniczym celem współpracy transgranicznej jest zniesienie barier wynikających $\mathrm{z}$ istnienia granic państwowych. Uwarunkowania historyczne i polityczne, takie jak obawa przed agresją militarna, preferowanie własnych narodowych struktur gospodarczych, spowodowały słabsze zaludnienie stref granicznych. Działalność gospodarcza, handel oraz ludność ciążyła ku centrom państw narodowych. Szlaki komunikacyjne biegły równolegle do granic. Granice naturalne, takie jak rzeki, jeziora, morza i góry potęgowały znaczenie granicy jako zapory. Ideologie polityczne oraz ambicje oddzielnych bloków militarnych przekształciły granice państwowe w szczelne rubieże. ${ }^{19}$

Pierwowzorem współpracy transgranicznej w Europie były euroregiony. Euroregionami nazywamy instytucje współpracy dwóch lub więcej jednostek reprezentujących regiony dwóch lub więcej państw (przynajmniej po jednym z każdego). Każda $\mathrm{z}$ nich jest powoływana na podstawie prawa wewnętrznego swojego kraju. Nazwa „euroregion” pochodzi od najstarszej inicjatywy współpracy transgranicznej „Euroregio”. Została ona powołana do życia w 1958 roku na obszarze przylegającym do granicy holendersko-niemieckiej, między rzekami Ren, Ems i Jssel. ${ }^{20}$

Wzrost znaczenia lokalnych ugrupowań regionalnych oraz regionów autonomicznych i transgranicznych doprowadził do instytucjonalizacji współpracy regionalnej w Europie zarówno na szczeblu poszczególnych regionów, jak i państw. W roku 1971 powstało Stowarzyszenie Europejskich Regionów Transgranicznych. W 1985 roku została utworzona Rada Regionów Europejskich, którą w dwa lata później zastapiło Zgromadzenie Regionów Europy. Pod auspicjami Rady Europy działała Stała Konferencja Władz Lokalnych i Regionalnych Europy. Obecnie jest to Kongres Władz Lokalnych i Regionalnych. Istotną rolę w kreowaniu działań na rzecz rozwoju regionów granicznych odegrało Stowarzyszenie Europejskich Regionów Granicznych (SERG), którego celem była wymiana doświadczeń i łączne reprezentowanie wspólnych interesów regionów granicznych. ${ }^{21}$

W wyniku współpracy Rady Europy z poszczególnymi stowarzyszeniami wypracowano szereg dokumentów regulujących zagadnienia związane ze współpracą transgraniczną i regionalną. Są to:

- Europejska Konwencja Ramowa o Współpracy Transgranicznej między Wspólnotami i Władzami Terytorialnymi sporządzona w Madrycie 21 maja $1980 \mathrm{roku}$;

Urząd Statystyczny we Wrocławiu, Euroregiony w granicach Polski, Wrocław 2007, s. 14.

M. Olszewski, Współpraca regionów - współpraca euroregionów, z: http://www.exporter.pl/zarzadzanie/patrz_ rowniez/unia_2 euroregiony.html

M. Lechwar, Geneza europejskiej instytucjonalizacji współpracy regionów granicznych, Materiały konferencyjne „Spójność społeczno-ekonomiczna a modernizacja regionów transgranicznych”, 21-23 listopada 2007, Rzeszów, Kolbuszowa, Berezka, s. 24-25. 
- Europejska Karta Regionów Przygranicznych sporządzona w Euroregio 19 listopada 1981 roku (od 1995 roku - Europejska Karta Regionów Granicznych i Transgranicznych);

- Europejska Karta Samorządu Terytorialnego sporządzona w Strasburgu 15 października 1985 roku;

- Europejska Karta Samorządu Regionalnego przyjęta w Strasburgu 5 czerwca 1997 roku przez Kongres Władz Lokalnych i Regionalnych Rady Europy. ${ }^{22}$

Europejska Konwencja Ramowa o współpracy transgranicznej między wspólnotami i władzami terytorialnymi, zwana Konwencją Madrycką ${ }^{23}$, jest dokumentem regulującym zagadnienia współpracy transgranicznej mającym priorytetowy charakter. Wspomniana Konwencja zakłada, że państwa członkowskie Rady Europy powinny nieustannie dążyć do tworzenia ściślejszych powiązań między sobą, wspierać się oraz współdziałać. Współpraca powinna obejmować możliwie wszystkie dziedziny życia kulturalnego, społecznego i gospodarczego, a także związane z nim infrastruktury Zaznacza przy tym, że realizacja tego celu będzie możliwa tylko poprzez współpracę między wspólnotami i władzami terytorialnymi obszarów przygranicznych. ${ }^{24}$

Konwencja Madrycka stworzyła definicję współpracy transgranicznej, która ma walor powszechny. W świetle jej regulacji za współpracę transgraniczną uznaje się „każde wspólnie podjęte działanie mające na celu umocnienie i dalszy rozwój sąsiedzkich kontaktów między wspólnotami i władzami terytorialnymi dwóch lub większej liczby Umawiających się Stron, jak również zawarcie porozumień i przyjęcie uzgodnień koniecznych do realizacji takich zamierzeń". ${ }^{25}$ Termin ten odnosi się do współpracujących regionów transgranicznych, jednolitych kompleksów terenów, wykazujących wspólne cechy, których ludność ma zbliżone tradycje kulturowe i wyraża chęć współpracy, w celu pobudzania rozwoju gospodarczego i kulturalnego. ${ }^{26}$

22 Zob.http://www.coe.org.pl/pl/rada_europy/wybrane_konwencje_i_inne_dokumenty.

23 Dokument Rady Europy, do którego przystapiło dotychczas 20 państw (stan na styczeń 2011r.), w tym także Polska w 1993 r.

24 M. Juchnicka, E. Skibicka-Sokołowska, Podstawy prawne i uwarunkowania współpracy transgranicznej, (w:) W. Bieńkowski, J. Grabowiecki, H. Wnorowski (red.), Współpraca transgraniczna Polski z krajami bałtyckimi, Białorusią i Rosja - Obwód Kaliningradzki. Uwarunkowania i perspektywy rozwoju. Materiały konferencyjne, Białystok 2002, s. 75.

25 Europejska Konwencja Ramowa o współpracy transgranicznej między wspólnotami i władzami terytorialnymi z 21 maja 1980 r. (Dz.U. z 1993 r. Nr 61 poz. 287).

26 M. Fic, Obszary przygraniczne w badaniach statystycznych. Materiały seminaryjne, regionalna statystyka transgraniczna, Jachranka 1995, (w:) Urząd Statystyczny w Jeleniej Górze, Panorama Euroregionów, Jelenia Góra 1998, s. $10-11$. 
Podmiotami współpracy transgranicznej mogą być różne jednostki terytorialne, zarówno samorządowe, jak władze lokalne i regionalne czy związki i stowarzyszenia JST oraz organy administracji rządowej. Jest to współpraca w pełni dobrowolna, powstająca na bazie związków ekonomicznych, geograficznych i społecznych, respektująca odmienną przynależność państwową zaangażowanych podmiotów. Opiera się na stosowanych umowach lub porozumieniach międzypaństwowych, które wskazują na warunki współpracy zgodnej z prawem wewnętrznym zainteresowanych stron. Współpraca transgraniczna nie zagraża integralności terytorialnej państw, gdyż nie znosi granic, lecz zbliża państwa, ucząc wspólnego rozwiązywania problemów i współistnienia. ${ }^{27}$

Obejmuje ona praktycznie wszystkie dziedziny życia społeczno-gospodarczego i politycznego, a prowadzona jest w zakresie:

a) infrastruktury technicznej, zagospodarowania przejść granicznych, układów komunikacyjnych, infrastruktury komunalnej;

b) gospodarki regionalnej i lokalnej, świadczenia usług, tworzenia izb przemysłowo-handlowych, działalności informacyjno-doradczej, promocji regionu i przedsiębiorstw;

c) sfery społecznej, jak rozwój demokracji lokalnej i regionalnej, wymiana kulturowa, sportowa, oświatowa, naukowa czy turystyczna;

d) ochrony środowiska przyrodniczego oraz obszarów chronionych;

e) tworzenia jednolitych koncepcji zagospodarowania przestrzennego obszarów transgranicznych..$^{28}$

Współpraca transgraniczna zapewnia również przepływ doświadczeń pomiędzy regionami z różnych państw, a tym samym wspiera działania zmierzające do podniesienia jakości funkcjonowania instytucji samorządowych, ułatwia rozwój turystyki, zapewnia koordynację rozbudowy infrastruktury po obu stronach granicy $i$ jest istotnym narzędziem promocji.

Zgodnie z Konwencją współpraca wspólnot i władz terytorialnych obszarów przygranicznych odnosi się do pięciu zasadniczych dziedzin:

1) rozwoju regionów, miast i wsi;

2) ochrony środowiska;

3) poprawy infrastruktury; 
4) rozwoju sektora usług dla ludności;

5) wzajemnej pomocy w razie nieszczęśliwych katastrof. ${ }^{29}$

Najważniejszą przesłanką współpracy między władzami lokalnymi i regionalnymi jest fakt poprawy stanu i rozwoju obszarów przygranicznych, a to z kolei wpływa na postęp gospodarczy i społeczny oraz umacnia poczucie więzi w państwach partnerskich. Artykuł 1 Konwencji w sposób wyraźny statuuje, że każda z umawiających się stron zobowiązuje się do ułatwiania i wspierania współpracy transgranicznej wspólnot i władz terytorialnych. Wspólnoty i władze terytorialne określone zostały przez Konwencję jako jednostki, urzędy i organy realizujące zadania lokalne i regionalne. ${ }^{30}$

Drugą część Konwencji stanowi aneks zawierający zestaw wzorcowy instrumentów prawnych, czyli wszelkich umów, porozumień i skutków dotyczących różnych form współpracy regionów przygranicznych. Jednak Konwencja nie zawiera wyraźnego postanowienia, które dawałoby władzom lokalnym i regionalnym poszczególnych państw możliwość nawiązywania współpracy. Możliwość taką wprowadził dopiero sporządzony w 1995 roku Protokół Dodatkowy do Konwencji ${ }^{31}$, w którym wyraźnie zaznaczono, że władze lokalne i regionalne wyposażone są w kompetencje do nawiązywania wszelkich działań związanych ze współpracą transgraniczna.. ${ }^{32}$

Polska, ratyfikując w 1993 r. Konwencję madrycką, przejęła na siebie zobowiązania dotyczące podejmowania działań na rzecz umacniania i rozwijania współpracy transgranicznej oraz rozwiązywania na drodze dwu- i wielostronnych uzgodnień problemów natury prawnej, administracyjnej i technicznej, które mogłyby tę współpracę zakłócić. ${ }^{33}$

Konwencja Madrycka stała się dźwignią rozwoju euroregionów w Polsce, wprowadzając wzorce i modele współpracy, nie narzucając gotowych rozwiązań. Z Konwencji Madryckiej wynikają również podstawowe zasady regulujące sposób funkcjonowania euroregionów:

- zasada consensusu - poszukiwanie wspólnego stanowiska poprzez rozmowy, negocjacje;

\footnotetext{
29 Europejska Konwencja Ramowa o współpracy transgranicznej między wspólnotami i władzami terytorialnymi z 21.05.1980, Dz.U. z 1993 r. Nr 61 poz. 287.

30 Na podstawie: Europejska Konwencja Ramowa o współpracy transgranicznej między wspólnotami i władzam terytorialnymi z 21.05.1980, Dz.U. z 1993 r. Nr 61 poz. 287, art. 1 i 2.

31 Protokół Dodatkowy do Europejskiej Konwencji Ramowej o współpracy transgranicznej między wspólnotami i władzami terytorialnymi, European Treaty Series (ETS) Nr 159.

32 M. Juchnicka, E. Skibicka-Sokołowska, op. cit., s. 76.

33 Z. Niewiadomski, Kierunki przemian polskiego systemu prawnego w sferze zagospodarowania i planowania przestrzennego, Warszawa 2001, s. 12.
} 
- zasada parytetu - we wszystkich organach każda ze stron dysponuje jednym głosem i taką samą reprezentacją liczbową;

- zasada rotacji - spotkania i konsultacje odbywają się kolejno u każdego $\mathrm{z}$ uczestników euroregionu; rotacyjnie sprawowane są również funkcje w ramach struktur euroregionów;

- zasada dobrowolności - poszczególne jednostki administracyjne samodzielnie podejmują decyzję $\mathrm{w}$ sprawie przystapienia do struktury euroregionalnej. ${ }^{34}$

Kolejnym ważnym dokumentem regulującym zagadnienia współpracy regionów jest Europejska Karta Regionów Granicznych i Transgranicznych. Po raz pierwszy została opracowana w 1981 r. podczas spotkania Stowarzyszenia Europejskich Regionów Granicznych pod nazwą Europejska Karta Regionów Przygranicznych. W 1995 r. nazwa dokumentu została zmieniona na Europejska Karta Regionów Granicznych i Transgranicznych. Dokument ten stanowi próbę podsumowania doświadczeń działalności Stowarzyszenia. Reguluje zasady współpracy regionów i tworzenia wzajemnego zaufania oraz współpracy między najbliższymi sąsiadami, określając kierunki wspólnego działania oraz rozwoju w regionach granicznych. ${ }^{35}$

Już w Preambule tego dokumentu zaznaczono wyraźnie, że granice są „bliznami historii". Współpraca transgraniczna ma zaś pomagać w łagodzeniu niekorzystnych skutków istnienia granic, a także w przezwyciężaniu skutków położenia terenów przygranicznych na narodowych obrzeżach państw oraz służyć poprawie warunków życiowych osiadłej tam ludności. Współpraca taka obejmować powinna wszystkie dziedziny życia kulturalnego, społecznego i gospodarczego oraz związanej z nimi infrastruktury. Wiedza o sąsiedzie i zrozumienie jego społecznej, kulturowej, językowej i ekonomicznej specyfiki, z których ostatecznie wyrasta wzajemne zaufanie, są warunkiem wszelkiej współpracy ponad granicami. ${ }^{36}$

Dokument określa pięć grup celów, które powinny być uwzględnione w dalszym rozwoju regionów granicznych i transgranicznych, a należą do nich:

1) zmiany charakteru granic i przezwyciężenie ograniczających do tej pory uregulowań krajowych, dotyczących nieprzenikalności granic;

2) tworzenie i umacnianie warunków ekonomicznych i społeczno-kulturalnych;

Publikacje Stowarzyszenia Euroregion Niemen udostępnione przez Biuro Stowarzyszenia przy ul. Wesołej 22 w Suwałkach.

35 Urząd Komitetu Integracji Europejskiej, Co reguluje Europejska Karta Regionów Granicznych i Transgranicznych?, http://www.cie.gov.pl

36 Europejska Karta Regionów Granicznych i Transgranicznych z 20.11.1981r. Nowelizacja z 2004 r., http://www. cie.gov.pl 
3) uznanie zdecentralizowanego charakteru regionów jako siły napędowej współpracy ponadgranicznej;

4) ułatwienie realizacji europejskiej polityki zagospodarowania przestrzennego;

5) usuwanie przeszkód i nierówności gospodarczych i infrastrukturalnych.

Za najważniejszy instrument prawny uznano w Karcie Konwencję Madrycką wraz z Protokołem Dodatkowym, równocześnie wskazując na konieczność stworzenia kolejnych ram prawnych i instytucji publicznoprawnych wspierających tę współprace. ${ }^{37}$

Pomimo że Europejska Karta Regionów Granicznych i Transgranicznych pozbawiona jest mocy prawnej oraz jest dokumentem o charakterze nieformalnym, determinując kluczowe zagadnienia polityki gospodarczej dotyczące europejskiej współpracy transgranicznej i przygranicznej, to Polska respektuje jej postanowienia od 1995 roku. $^{38}$

Dokumenty, które wyposażają władze lokalne i regionalne w uprawnienia do podejmowania współpracy, to Europejska Karta Samorządu Terytorialnego ${ }^{39}$ z 1985 roku oraz Europejska Karta Samorządu Regionalnego ${ }^{40}$ z 1997 roku.

Pierwszy z wyżej wymienionych dokumentów stanowi zbiór kilkudziesięciu zasad, którymi powinny kierować się państwa podczas formułowania ustawodawstwa komunalnego i którym musi odpowiadać już istniejące prawodawstwo. Przyjęcie tych reguł oznacza akceptację podstawowych cech i gwarancji niezależności oraz samodzielności struktur samorządu terytorialnego; gwarancje te występują w szczególności na płaszczyźnie źródeł prawnej regulacji statusu instytucji samorządowych, finansowej oraz nadzorczo-kontrolnej.

Państwa-strony Karty zobowiązały się do osiagania sześciu celów sformułowanych w dokumencie, a mianowicie:

1) włączenie gmin i regionów w realizację integracji europejskiej;

2) budowy Europy w oparciu o zasady demokracji i decentralizacji;

T. Borys, J. Zaucha, Wstęp, (w:) Urząd Statystyczny w Jeleniej Górze, Panorama Euroregionów, Jelenia Góra 1998, s. 28.

38 M. Kołodziejski, K. Szmigiel, Międzynarodowa współpraca transgraniczna i międzyregionalna w kontekście polityki regionalnej państwa na lata 2007-2013, Warszawa 2004, s. 8-10.

39 Dz.U. z 1994 r. Nr 124 poz. 607.

40 Polska nie ratyfikowała Europejskiej Karty Samorządu Regionalnego (stan na styczeń 2011 r.). W tej sytuacji trudno mówić o zobowiązaniach wynikających z realizacji jej ustaleń. Spodziewana ratyfikacja spowoduje konieczność powrotu do analizy ustaleń Karty. Polska nie ratyfikowała Karty uzasadniając, że jest ona niemalże identyczna w swoich postanowieniach, jak Europejska Karta Samorządu Terytorialnego 
3) budowy Europy Obywateli przez włączenie obywateli w tworzenie demokracji w miejscu zamieszkania;

4) materializacji zasady closer to citizen przez skuteczne zarządzanie na szczeblu lokalnym w bezpośredniej bliskości obywatela;

5) materializacji zasady subsydiarności jako zasady kształtującej kompetencje szczebla lokalnego;

6) rozwój współpracy pomiędzy gminami i regionami europejskimi.

Karta odnosi się do odpowiedzialności obywateli i zasady samorządu lokalnego jako głównych elementów efektywnej demokracji i wymaga ich uznania w prawie krajowym i w „miarę możliwości w Konstytucji” (art. 2). Stanowi istotny wkład w rozwój idei społeczeństwa obywatelskiego. Przyjęta później Europejska Karta Samorządu Regionalnego podejmuje przede wszystkim zagadnienia związane z regionem - jako elementem państwa odzwierciedlającym europejskie zróżnicowanie i przyczyniającym się do wzbogacania jego kultury.

Zgodnie z artykułem 3 Karty „Samorząd regionalny oznacza prawo i zdolność największych terytorialnych jednostek władzy w obrębie każdego państwa, mających wybieralne organy, administracyjnie umieszczonych między rządem centralnym i samorządem lokalnym, i posiadających prerogatywy, albo wynikające z samoorganizacji albo typu zwykle przypisywanego rządowi centralnemu, do zarządzania na własną odpowiedzialność i w interesie mieszkańców zasadniczą częścią spraw publicznych, zgodnie z zasadą subsydiarności”"41, Regiony zaś są uważane za zdefiniowany podmiot samorządowy prowadzą własną politykę i szeroko zakrojoną współpracę międzynarodową.

Karta określa szereg zasad, którymi muszą kierować się państwa do niej przystępujące. Wśród tych zasad wyróżnić można między innymi:

- zakaz zmiany granic regionów bez ich zgody;

- rozstrzyganie konfliktów kompetencji między regionami a rządem centralnym wyłącznie przez sądy;

- precyzję delegacji kompetencji władz centralnych do regionów;

- prawo regionów do uczestnictwa, poprzez ciała specjalnie do tego przeznaczone, w działalności instytucji europejskich;

- stosowanie zasady subsydiarności w stosunkach z władzami lokalnymi; 
- prawo regionów do udziału w sprawach państwa, w tym zwłaszcza w procedurze stanowienia aktów prawnych zmieniających kompetencje lub dotykających interesów regionów;

- delegowanie kompetencji na rzecz władz lokalnych wyłącznie w granicach określonych przez prawo i precyzyjne określenie zakresu takiej delegacji. ${ }^{42}$

Pomimo że Polska nie ratyfikowała Europejskiej Karty Samorządu Regionalnego polskie ustawodawstwo jest - generalnie rzecz biorąc - zgodne z postanowieniami Karty. Nie dotyczy to jednak wszystkich postanowień tego dokumentu. I tak na przykład ustawa z dnia 15 września 2000 r. o zasadach przystępowania jednostek samorządu terytorialnego do międzynarodowych zrzeszeń społeczności lokalnych i regionalnych ${ }^{43}$, będąca krajową podstawą prawną przystępowania jednostek samorządu terytorialnego w Polsce do tzw. euroregionów, wyklucza możliwość przekazywania przez jednostki samorządu terytorialnego przystępujące do tego rodzaju zrzeszeń wykonywania jakichkolwiek zadań publicznych, a także nieruchomości i praw majątkowych na dobrach niematerialnych na rzecz takich zrzeszeń lub poszczególnych ich członków. Jest to sprzeczne z przepisem Karty upoważniającym regiony transgraniczne do tworzenia wspólnych organów przedstawicielskich i wykonawczych. ${ }^{44}$

Niewatpliwie wsparcia instytucjonalnego regionom udziela Rada Europy. Jest ona (od co najmniej kilkudziesięciu lat) źródłem inspiracji i pomysłów dla współpracy regionalnej i transgranicznej. Rada Europy uznawała od dawna, że demokracja na szczeblu lokalnym i regionalnym spełnia nadrzędną rolę. Samorządy lokalne muszą spełniać potrzeby wszystkich Europejczyków, w miastach i na wsiach, w regionach centralnych, peryferyjnych i granicznych. W 1957 roku Rada Europy podjęła pierwsze kroki w celu zapewnienia reprezentacji władz lokalnych w ramach realizowanej przez nią aktywności. Jej działalność w tym zakresie obejmuje terytorium od Islandii po Rosję i od Norwegii po Bałkany. W 1994 roku Rada Europy powołała do życia, jako ciało o charakterze konsultacyjnym, Kongres Władz Lokalnych i Regionalnych Europy (CLRAE), obecnie - Kongres Władz Lokalnych i Regionalnych Rady Europy, który zastąpił Stałą Konferencję Władz Lokalnych i Regionalnych. Kongres niesie pomoc nowym państwom członkowskim w kwestiach praktycznych związanych z tworzeniem skutecznie działających samorządów lokalnych i regionalnych. ${ }^{45}$

42 S. Malarski, Regiony i euroregiony - założenia organizacyjne, prawne i administracyjne, Opole 2003, s. 136137.

43 Dz.U. z 2002 r. Nr 113 poz. 984.

44 Leksykon Samorządu Terytorialnego, Europejska Karta Samorządu Regionalnego, http://samorzady.polska.pl/ leksykon/index,Europejska_Karta_Samorzadu_Regionalnego,id,419869.htm

45 Biuro Informacji Rady Europy, Rada Europy: informacje ogólne - struktura, http://www.coe.org.pl/pl/rada_europy/struktura\#kongres 
Kongres Władz Lokalnych i Regionalnych Rady Europy jest wyspecjalizowaną instytucją reprezentującą samorządowe władze lokalne i regionalne i realizującą funkcje opiniodawcze i doradcze. W jego skład wchodzą przedstawiciele państw członkowskich Rady Europy, czyli przedstawiciele samorządów wybierani przez organizacje samorządowe lub ich reprezentacje. W świetle uchwały statutowej Kongres:

- jest głosem europejskich regionów, miast i gmin,

- doradza Komitetowi Ministrów i Zgromadzeniu Parlamentarnemu Rady Europy we wszystkich aspektach polityki lokalnej i regionalnej,

- współpracuje ściśle z organizacjami krajowymi i międzynarodowymi, reprezentując samorządy lokalne i regionalne,

- organizuje publiczne debaty i konferencje, pragnąc dotrzeć do szerokich kręgów społeczeństwa, których zaangażowanie jest bardzo istotne w tworzeniu demokracji,

- przygotowuje raporty na temat stopnia rozwoju demokracji lokalnej i regionalnej we wszystkich państwach członkowskich i w krajach ubiegających się o członkostwo oraz prowadzi monitoring, szczególnie realizacji zasad zawartych m.in. w Europejskiej Karcie Samorządu Terytorialnego. ${ }^{46}$

Najważniejszym osiagnięciem Kongresu jest opracowanie projektu Europejskiej Karty Samorządu Regionalnego. Po 3 latach konsultacji i ustaleń Karta została przyjęta na IV sesji plenarnej w dniach 3-5 czerwca 1997 roku. Kongres, w wyniku rozszerzenia Rady Europy o państwa Europy Środkowej i Wschodniej, stał się podstawową platformą współpracy władz lokalnych i regionalnych w integrującej się Europie. Niewątpliwie przyczynia się do ożywienia współpracy regionalnej i transgranicznej na rzecz pokoju, tolerancji i zrównoważonego rozwoju. ${ }^{47}$

\section{Uwagi końcowe}

Współpraca transgraniczna jest instrumentem pozwalającym minimalizować negatywne konsekwencje wynikające $\mathrm{z}$ istnienia szczelnej granicy państwowej. Ma bowiem na celu stymulowanie i rozwijanie kontaktów pomiędzy społecznościami zamieszkującymi tereny przygraniczne, przełamywanie zagrożeń wynikających z faktu występowania dysproporcji ekonomiczno-społecznych regionów po 
obu stronach granicy, a także niwelowanie przeszkód związanych z nierównowagą gospodarczą regionów oraz różnym stopniem rozwoju infrastruktury techniczno-komunikacyjnej. ${ }^{48}$

Po II wojnie światowej współpraca transgraniczna zyskała nową jakość. Najpierw w Europie Zachodniej, później po 1989 roku w Europie Środkowej i Wschodniej dostrzeżono znaczenie współpracy regionów. Analizując współczesne stosunki międzynarodowe, dostrzega się fakt, że to właśnie w skali regionu występuje większa możliwość stworzenia sprawnie działających mechanizmów współpracy. To właśnie obserwując ten rodzaj współpracy, najłatwiej znaleźć można punkty styczne dla priorytetów społecznych, gospodarczych i politycznych.

Kontakty regionów sąsiedzkich są najlepszym przykładem oddolnej obywatelskiej samoorganizacji społeczeństwa. Administracja centralna państw uczestniczących w stosunkach bilateralnych (bądź multilateralnych) służy tylko za pomost realizacji inicjatyw, które zwykle rodzą się na poziomie kontaktów międzyludzkich, a nie na poziomie zorganizowanej polityki zagranicznej. Dzięki temu redukuje się do minimum udział państwa w procesie wymiany doświadczeń i informacji pomiędzy różnymi narodami, które widząc korzyści z wzajemnej współpracy, same dążą do realizacji wspólnych przedsięwzięć polityczno-gospodarczo-społecznych.

Współpraca transgraniczna i współpraca regionalna stanowią ważny element polityki zagranicznej państwa. Niewątpliwie są jednym z głównych czynników sprawczych szybszego i intensywniejszego rozwoju regionów. Świadczy o tym przede wszystkim podjęcie uregulowania kwestii z nimi związanych najpierw przez Radę Europy, a następnie przez Unię Europejska. Dzięki legislacji Rady Europy w postaci Konwencji Madryckiej, Europejskiej Karty Samorządu Terytorialnego czy Europejskiej Karty Regionów Granicznych i Transgranicznych systematycznie rozwijają się regulacje krajowe w dziedzinie współpracy władz lokalnych i regionalnych z ich odpowiednikami w państwach sąsiedzkich. Dzięki wsparciu finansowemu Unii Europejskiej graniczące ze sobą regiony (nie tylko państw członkowskich, ale i krajów trzecich) mogą rozwiązywać, poprzez podejmowanie wspólnych działań, wspólne regionalne problemy. Dzięki uregulowaniom kwestii współpracy transgranicznej nawet granica państwowa, uważana jeszcze niedawno za największą barierę we wzajemnych stosunkach regionów, nie stanowi obecnie już takiej przeszkody w podejmowaniu wspólnych działań.

Unia Europejska nie skupia się wyłącznie na programach i działaniach wspierających rozwój wewnętrzny regionów. Popierając takie inicjatywy, jak programy 
w ramach Europejskiej Polityki Sąsiedztwa ${ }^{49}$, współpracy euroregionalnej czy zawieranie porozumień dotyczących małego ruchu granicznego ${ }^{50}$, Unia Europejska w bardzo wysokim stopniu wpływa na rozwój regionów w państwach trzecich. ${ }^{51}$

49 Komunikat Komisji do Rady i Parlamentu Europejskiego, Europejska Polityka Sąsiedztwa - strategia, 12.05.2004 r., COM(2004)373 final.

50 Rozporządzenie (WE) nr 1931/2006 Parlamentu Europejskiego i Rady z dnia 20 grudnia 2006 r. ustanawiajace przepisy dotyczące małego ruchu granicznego na zewnętrznych granicach lądowych państw członkowskich i zmieniające postanowienia Konwencji z Schengen, Dz. Urz. UE L 405 z 30 grudnia 2006, s. 1-22.

51 W. Kosiedowski, Regiony Europy środkowo-wschodniej w procesie integracji. Ze szczególnym uwzględnieniem wschodniego pogranicza Unii Europejskiej, Toruń 2008, s. 99-100. 


\section{ОСНОВНЫЕ ПРАВОВЫЕ ИНСТРУМЕНТЫ ТРАНСГРАНИЧНОГО СОТРУДНИЧЕСТВА В РАМКАХ СОВЕТА ЕВРОПЫ}

C развитием международного сотрудничества государств неразрывно связаны интеграционные общественно-экономические процессы местных и региональных территориальных образований. Государства перестают быть важнейшими действующими лицами на международной арене. На протяжении последних лет международные отношения подверглись значительной децентрализации. В настоящее время центральная власть государств должна делить международное пространство с региональными и местными властями. Первые международные нормы, дающие общие дефиниции и примерные механизмы установления трансграничного сотрудничества, появились лишь в 1980 году и были выработаны в рамках Совета Европы. По настоящее время Европейская рамочная конвенция о трансграничном сотрудничестве между территориальными образованиямиявляется основным источником в установлении сотрудничества между регионами, и разработанная концепция трансграничного сотрудничества одобряется всеми.

Трансграничное сотрудничество является инструментом, позволяющим минимизировать негативные последствия, вытекающие из существования государственной границы. Целью его является стимулирование и развитие контактов среди местного населения, проживающего на приграничных территориях, преодоление нежелательных последствий, вытекающих из общественно-экономических диспропорций регионов по обеим сторонам границы.

После Второй Мировой войны трансграничное сотрудничество приобрело новое качество. Сперва в Западной Европе, а затем, в 1989 году, в Центральной и Восточной Европе обратили внимание на значение сотрудничества регионов. При анализе современных международных отношений отмечается, что именно на уровне регионов существует больше возможностей для создания исправно действующих механизмов сотрудничества. Наблюдая за сотрудничеством этого уровня, проще всего найти точки соприкосновения общественных, экономических и политических приоритетов.

Трансграничное и региональное сотрудничество составляет существенный элемент внешней политики государства. Несомненно, оно является одним из важных движущих факторов быстрого и интенсивного развития регионов. Об этом прежде всего свидетельствует попытка урегулировать связанные с ним 
вопросы сперва Советом Европы, а затем Евросоюзом. Благодаря таким актам нормотворчества Совета Европы, как Мадридская конвенция, Европейская хартия территориального самоуправления, Европейская хартия приграничных и трансграничных регионов, систематически развивается двустороннее и национальное правовое регулирование в области сотрудничества местных и региональных властей с аналогичными властями соседних государств. При финансовой поддержке Евросоюза граничащие друг с другом регионы (не только государств-членов ЕС, но и третьих государств) могут решать, предпринимая совместные действия, общие для них вопросы. Благодаря решению вопросов трансграничного сотрудничества даже государственная граница, которая еще недавно считалась барьером во взаимоотношениях регионов, в настоящее время уже не является преградой для совместных действий.

Усилия Евросоюза направлены не только на создание программ содействия внутреннему развитию регионов. Поддерживая такие инициативы, как программы в рамках Европейской политики соседства, еврорегионального сотрудничества или заключения договоров, касающихся малого приграничного движения, ЕС оказывает существенное влияние и на развитие регионов в третьих государствах. 


\section{THE BASIC LEGAL INSTRUMENTS FOR CROSS-BORDER COOPERATION IN THE FRAMEWORK OF THE COUNCIL OF EUROPE}

The socio-economic processes of the integration of local and regional communities is inextricably connected with the development of international cooperation. States have ceased to be the most important actors on the international scene. Over recent years, international relations have undergone substantial decentralization, and the international system has been filled by many different agencies. The central authorities of the Member States are obliged to share international space with regional and local authorities. The first international regulations, setting out common definitions and model-driven mechanisms for cross-border cooperation appeared only in 1980 and were developed with in the framework of the Council of Europe. Up until the present, the European Framework Convention on cross-border cooperation of territorial communities and authorities has been a fundamental source of inspiration for cooperation between regions, and the definition of cross-border cooperation provided, has been widely accepted.

Cross-border cooperation is an instrument to minimize the negative consequences arising from the existence of tight national frontiers. Its aim is to encourage and develop contacts between communities residing in the border areas, overcoming the risks arising from the fact of socio-economic disparities between the regions on both sides of the border.

The European Union does not focus exclusively on programs and activities supporting the internal development of the regions. In supporting such initiatives as programs in the framework of the European neighbourhood policy, cooperation of euro regions, agreements on local border traffic, it largely affects the development of regions in third countries.

Key words:

Cross-border cooperation, euro region, border, the Council of Europe, the European Union 